\title{
Marketing Strategy in Political Competition: A Case of the Campaign Team Samahuddin and La ntau
}

Riki

Faculty of Economics and Business, Universitas Brawijaya, Indonesia ricki.saliwu@gmail.com

\section{Wahdiyat Moko}

Faculty of Economics and Business, Universitas Brawijaya, Indonesia

\section{Atim Djazuli}

Faculty of Economics and Business, Universitas Brawijaya, Indonesia

\begin{abstract}
This study aims to understand and explore the political marketing strategy of SAMATAU's campaign team in winning the political competition at the local level. Using a single Holistic interpretative case study (Robert K Yin, 2011), on the campaign team of Samahuddin - La Ntau, in this case as, the incumbent challenger as well as the winner of the Regent Election in 2017. The results of the study show that although the Samahuddin-La Ntau couple was categorized as a newcomer to the political competition, the campaign team of SAMATAU had several conditions and strategies in winning the competition including surveying and grouping voters, understand the characteristics and nature of voters, target actions, political image formations (framing), and also implementation of political programs that include political products, political campaigns, political venues, and political capital. In order to control the political programs that have been designed by the contestant, then the SAMATAU team conducts scheduled and unscheduled monitoring and evaluation. The implication of this study is that political marketing strategies give information to politicians, where this strategy is a systematic approach to help competitors in winning political competition.
\end{abstract}

KEYWORDS : SAMATAU Team, Political Marketing, Competitive Advantage Strategy, Personal Branding, Newcomers

\section{INTRODUCTION}

In this era, the marketing strategy is not only used in winning the competition in the commercial market but has also been widely used in the context of political marketing. The expansion of this marketing strategy is inseparable from the factor of the similarity and difference between commercial marketing and political marketing (Potincu, 2009). The benefit of marketing strategy is as an instrument to facilitate competitors in winning the competition in the political market. Therefore in this context, the researcher will explore the political marketing strategy between the incumbent (old player) and the newcomer in winning competition of regent election for Central Buton District in 2017.

Berry et al. (2000), in their study, found that incumbents or old players "in the world of politics" always have the opportunity to win every participation when the momentum of the general election is held, as well as the results of the study conducted by Vaishnav \& 
Guy (2018). Firmanzah (2008) in Sugiarto (2014) revealed that in addition to incumbents having support from several circles and solid political power, the incumbent candidate also was benefited from good image positioning as the official who was popular in the eyes of the people. Furthermore, if this process is supported by the performance of professional figures, positive and good during his administration, it will certainly strengthen the correlation between voters and candidates in terms of gaining victory in the competition.

Another factor that causes incumbent victory is having a professional attitude in every contestation, resource excellence, political costs and understanding of voters' needs based on demographic data that has been identified during their period, as well as the attitude of confidence that is not possessed by challengers (Berry et al., 2000). In addition, (Mehta, 2009), (Naig, 2016) in the 2008 US presidential election, professionally incumbents used national voters' files to find out what messages were most in line with the voters' needs, so that when the candidates design the vision and mission as much as possible they can adjust the message to them based on the basic needs of the voters recorded in the file. Furthermore.

On the other hand, it is different from the result of the contestation of regent election in Central Buton in 2017, Samahuddin-La Ntau which is categorized as the newcomers in the political competition is able to win the competition. Political competition between challengers and incumbents certainly will not succeed in the management of political marketing strategies, if they do not have a solid and loyal team in playing the role of a campaign team. Therefore, based on these phenomena, this study aims to explore the success of the strategy of the campaign team of Samahuddin-La Ntau in winning the political competition of regent election in 2017.

\section{LITERATURE REVIEW (AND OR HYPOTESHIS)}

\section{Political Marketing Strategy}

Kotler (1976), in Potincu (2009) divides the functions of marketing science into two parts, namely economic marketing and non-economic (non-profit/social) marketing. However, by the development of behavior and social market orientation, non-economic marketing is specified in the realm of political marketing. In line with Newman (1994), in his book entitled "The Marketing of the President" explains that although political marketing seeks to be integrated with economics, it cannot be denied if there are some similarities/differences between political marketing and product marketing theories commercial consumption or marketing. Political marketing is explained, as a scientific discipline that originally adopted from the economic literature then developed into a framework of thought based on the perspective of political science (Lock \& Harris, 1996). According to Potincu (2009) principally, the functions of political marketing are to carry out campaigns, both for personal and party. Means that commercial marketing is a product of production, while in marketing politics is a candidate figure, character, through a marketing strategy that may not different from business marketing in general.

34 Management and Economics Journal (MEC-J) Vol 4 (1) April 2020 
Table 1. Differences in commercial marketing and political marketing

\begin{tabular}{ll}
\hline Commercial Marketing & Column Header Goes Here \\
\hline Product & Party, candidate, political program and ideology \\
Market Commodities & $\begin{array}{l}\text { Constituents or Citizens/Communities that have voting } \\
\text { rights } \\
\text { Consumer }\end{array}$ \\
$\begin{array}{l}\text { Party, candidate, political program and ideology } \\
\text { Exchanges }\end{array}$ & $\begin{array}{l}\text { Constituents or Citizens/Communities that have voting } \\
\text { rights }\end{array}$ \\
\hline
\end{tabular}

Source :Potincu (2009)

Kotler (2001), In the marketing business, the seller sends goods, services, and communications (in the form of advertisements) to the market with refunds (consumer purchases), information and customer loyalty. While in political campaigns, the candidate sends promises, policy preferences, personalities and behavior, voluntary efforts or candidate contributions to the voter market. Harris \& Lock (2010), In the context of political marketing, marketers pursue an increase in adhesion to political parties, candidates or programs in one or more of the electoral groups are intended. In management strategy point of views, the concepts and procedures are used as instruments to win the competition when competing, whether in the business domain or in the political sphere. In this case, competitors need to implement strategies and theoretical concepts based on the relevance of the marketing environment, when faced with competition in the political market (Lees Marsment, 2011).

Political marketing strategies can be interpreted as the implementation of theories, concepts, orientations, and commercial marketing tools to the political environment (O'Cass 2001; Speed, Butler, and Collins InPich, 2018). This has been developed simultaneously as a subdiscipline of marketing since the seminar of Lock and Harris (1996) was put forward, and also become an extraordinary field of study "outside of the art of black propaganda" developed by (Harris and Lock, 2010), on a development of management strategies especially in political marketing to win competition (Pich, 2018).

\section{Political Competitive Advantage}

According to Lees Marsment (2011), revealed that in the strategy of winning competition, competitors need to identify and position themselves by using market analysis to assess where politicians and parties are related to each other and tell how to respond to these competitors. (Baines et al, 2002), The function of this strategy is an effort by competitors to know the difference between competitors and one another. Besides that, politicians and political parties usually develop different strategies to achieve political goals and objectives. Osuagwu(2008), the strategy is certainly based on the corridor that has been designed and established in winning the hearts of voters in the political marketing concept. (Newman, 1994), strategic management of competitive advantage can be conceptualized as a three-phase process that includes: first, analysis of the external and internal environment; second, formulating strategies that are in 
accordance with the organization; and third, Implementation and control of the strategy.

Phillips \& Reynolds (2010), in winning competition there are several basic requirements, one of which is to segment the market in the prevailing commercial trade market, and vice versa in political marketing, there are three criteria include suitability, identifiability, and reachability. The use of each of these criteria based on the logic that the market must be large enough to benefit the contestants, and at the same time, marketers must be able to identify who consumers can reach them with what they have. Then, marketers are involved in what is called "Target Marketing" according to Kotler in (Newman, 1994). The most common theory for political marketing is the Three Phase Model of Keith(1960). The first is identifying public demand, the accuracy in implementing the vision and mission and adaptation to the environment. Second is spread the program to the public. The third is the implementation of political programs in order to change voter behavior in achieving political market leadership.

\section{METHODOLOGY}

This study was designed using a qualitative approach by defining qualitative methods as research procedures that produce descriptive data in the form of written or oral words from people and observable behavior (Moleong, 2016). According to Yin (2011), there are four types of case study design including; 1) The single holistic case design, 2) Single intertwined case design, 3) Holistic multi-case design, 4) Intertwined multi-case design. In this study, the researcher used single holistic case study by focusing one case on how the success of the political marketing strategy of the campaign team of Samahudin - La Ntau won the competition of regent election in 2017.

Figure. 1 : Data analysis Technique



Source : Yin (2011)

The first part of data collection is in the form of results from interviews, field observations, and documents analysis obtained from the campaign team of Samahuddin-La Ntau. The second is data reduction, in this step, the analysis can reinforce, shorten, and more focus and also eliminate things that are considered insignificant. The third is the presentation of data, a process of rearranging or integrating information in a structured and systematic manner, in addition, the researcher will combine and compile the relationships between the data obtained previously, and describe the process of the phenomenon of the campaign team of Samahuddin-La Ntau. The fourth is the data interpretation, in this step, the researcher 
makes a new narration from the research. Making the narrative using tables and graphs supported by relevant data and will be a major analysis in the research manuscript. So that through this process, the researcher will reduce and present data differently, with the reason that all of these sequences begin with one-way and two-way arrows. The fifth stage is the conclusion, in this step, the researcher will draw the conclusion based on the data analysis or this step is a process of describing all research results. In addition, this validity test uses 5 Creswell methods (2016), namely the prolonged engagement and persistent observation test. The triangulation test used is the triangulation method, thick description test, Peer-reviewed, and Member check test.

\section{RESULTS AND DISCUSSION}

\section{Determination Of The Voters Segment}

Based on the results of interviews that the researcher has been conducted to some informants, implicitly the campaign team of Samahuddin-La Ntau gave its own meaning regarding the results of the survey that had been identified based on the voters in Central Buton political market, which included traditional voters, rational voters and transactional voters. The heterogeneous grouping of voters into homogeneous voters are aimed to facilitate the campaign team in distributing political programs based on the needs and preferences of voters in Central Buton Regency. (Haris\& Lock, 2010), the strategy of dividing voters into different voter segments and then creating a campaign platform that appeals to voters when the Election Day. In addition, according to (Newman, 1994), the method of dividing voter groups or market segmentation has the ability to divide voters into different segments for the accuracy of offerings political program. Analysis of voter segmentation is used because candidates realize that their products and services cannot satisfy or represent all of the voters' interests.

\section{Understand The Typology Of Voters}

In understanding the characteristics of traditional, rational and transactional voters, the campaign team of Samahudin-La Ntau gave a specific explanation in interpreting the characteristics of these voters. The process aims for the accuracy in the distribution of political programs based on the needs of voters. Besides, this process is a step to find out the diversity of voters in making decisions in conducting elections.

Table 2. Understand the typology of voters

Typology of voters Information

\begin{tabular}{ll}
\hline \multirow{3}{*}{ Traditional voters } & - Emotional Family Voters \\
Rational voters & - The similarity in Culture, customs, ethnicity, religion \\
& - The similarity of Local identity \\
& - Vision and mission \\
& - Preferences \\
Transactional voters & - Candidate quality \\
& - Based on payment (Money Politic) \\
& - How much value is obtained \\
& - There is no long-term prospects \\
& - Emotional Family Voters \\
& - The similarity in Culture, customs, ethnicity, religion \\
& - The similarity of Local identity
\end{tabular}


The findings of this study explicitly have been supported by several findings regarding the characteristics of traditional, rational and transactional voters. For examples, (Rohrscheneider, 2002), traditional voters are those who have the personality of commitment to what has become the initial decision in making elections, which means that these voters are easily mobilized by propaganda on ethnic, regional and religious issues adopted by the voters. Another characteristic of those voters, namely the visionmission or platform is not important but the important is the figure and regional identity that the candidates have.

Moreover, (O'Shaughnessy, 2002) in (Peng\&Hackley, 2009), for rational voters are those who are more dominant looking for symbols that have values related to political parties and candidates to shape the political image in the future. In this context, rational voters will be more sensitive related to the preferences offered by candidates for their future job. While for transactional voters, according to (Neffenegger, 1989), (Newman, 1994), they are more impulsive than to choose rationally. It means that, they are relatively easy to be persuaded by certain arguments in the form of material (money), but sometimes they are also more difficult to reach because usually, they are not interested in the politics that happened at that time unless there is something that they get.

\section{Target of Political Action}

The campaign team of the Samahuddin-La Ntau set the target for political action in all voter groups in Central Buton Regency. However, based on the plenary of the Regional General Elimination Commission (KPUD), the Central Buton Final Voters (DPT) list totaling 76,582 votes, from this data, the percentage of the target team of SamahuddinLa Ntau was $65 \%$ or 49,778 votes. Moreover, the campaign team has voter priorities which will be focused on being organized; they are among the traditional voters and rational voters. These voters are prioritized because they have a significant influence in their environment to invite and mobilize the other voters. In line with the findings of this study and the meanings are conveyed by several informants, conceptually supported the theory from Kotler(1999). In this case, after the voter group segment is successfully identified, the next step is targeting organizational achievements and then prioritized the consumers' needs to do marketing. In addition, the general criteria used in prioritizing the target are they must be measurable and accountable when carrying out work in the field with the system of company member performance evaluation.

\section{Formation of Political Branding}

In gathering information conducted by researchers to some informants related to the formation of political branding of Samahuddin-La Ntau during the momentum of the Regent election, implicitly some informants gave their own meaning on the topic that was intended by the researcher, in forming a political branding consisting of 6 stages carried out by the campaign team of Samahuddin-La Ntau, including; 1) direct selling, 2) identity political propaganda, 3) propaganda of political programs, 4) propaganda of political jargon, 5) social investment, 6) principle of idealism possessed by candidates. Philips et al. (2010), the method of direct selling of products (direct selling) or conducting face-to-face voters is a way to make an emotional connection between political products and voter communities. While regarding propaganda of political jargon is an attitude to shape the political image of candidates in the voter market. Political propaganda is a message of mass communication, adopted from Habermas's thought 
(Habib, 2007), a figure of critical theory and postmodernism, the message of jargon is an attempt to shape the image in achieving the goal. In this case, the purpose of propaganda depends on who uses it and who will be addressed. From several research references, it has supported the results of informants' statements about the interpretation of political branding in Central Buton Regency.

\section{Implementation of Political Programs}

The result of Interviews that interpreted by the campaign team of Samahuddin-La Ntau, they have own perception based on the political dynamics that occur in the field. They revealed that in the political context there are planning, supervision, and evaluation. The implementation of the political program carried out by the campaign team has five important points to win the voter group and become the winner of Regent election in Central Buton regency in 2017, including; 1) political products, 2) political campaigns, 3) political places, 4) political capital, 5) monitoring and evaluation.

1. The realization of political products interpreted by the campaign team of Samahuddin-La Ntau is about the accuracy of the preferences offered to the voter market, personal branding, and ideology of political parties that support SamahuddinLa Ntau (PDIP, PKB, PKS, Nasdem, PPP). Preference means that is about the basic needs of the voter group and personal branding is promoting the candidates related to their track records that have social values, while promoting the ideology of political parties includes the principles of religion, culture, and Modernism which are establishing and utilizing party relations for regional development.

2. The way of political campaigns conducted by the campaign team to introduce political programs is by social media, print/electronic media, and direct selling. The social media used by the campaign team of Samahuddin-La Ntau is Facebook and Instagram in the name of "SAMATAU's Friend". In print media, the campaign team cooperates with local media such as ButonPos, and KeptonPos. Meanwhile, through direct selling for the campaign team of Samahuddin-La Ntau, the most effective method for inviting and introducing the political products of Samahuddin-La Ntau is through direct visits and campaigns (face to face), in order to establish the emotional connection between candidates and voters.

3. The political place is the connotation of the campaign team posts for organizing, gathering, and doing political agendas. Campaign post for the SAMATAU team is a strategic step to distribute political programs throughout sub-districts, villages in Central Buton. Niffenegger (1989), a political place or campaign post is closely related to the presence of political institutions or competitors in distributing their political ideas and programs to voters or potential voters, and certainly, the programs are related to voters' needs.

4. In the context of the political capital, the campaign team of Samahuddin-La Ntau gives its own perception regarding political capital that needs to be prepared before the contestation of post-conflict local elections. Perception of the campaign team of Samahuddin-La Ntau regarding political capital consists of two parts, namely social political capital and political economy capital. Social capital is related to track records of prospective partners in the social environment, while economic capital covers operational costs to facilitate the campaign team's work.

5. From the four implementations of the political program, the last step is monitoring and evaluating the performance of the team and voters in the field. The campaign team executes this on a scheduled and unscheduled basis. Scheduled means that it is 
done formally which is attended by all of the teams from village to the district team, while unscheduled activities are based on the dynamics that occur in the field.

According to Kotler (1989) in Newman (1994), During the selection process, candidates and consultants are constantly reviewing/controlling in progress, in the quotation as follows: "A marketing monitoring system is used to measure the results of an ongoing plan against the purpose of the plan and to take corrective action before it's too late. Corrective action is possible to change goals, plans, or implementations with new situations."

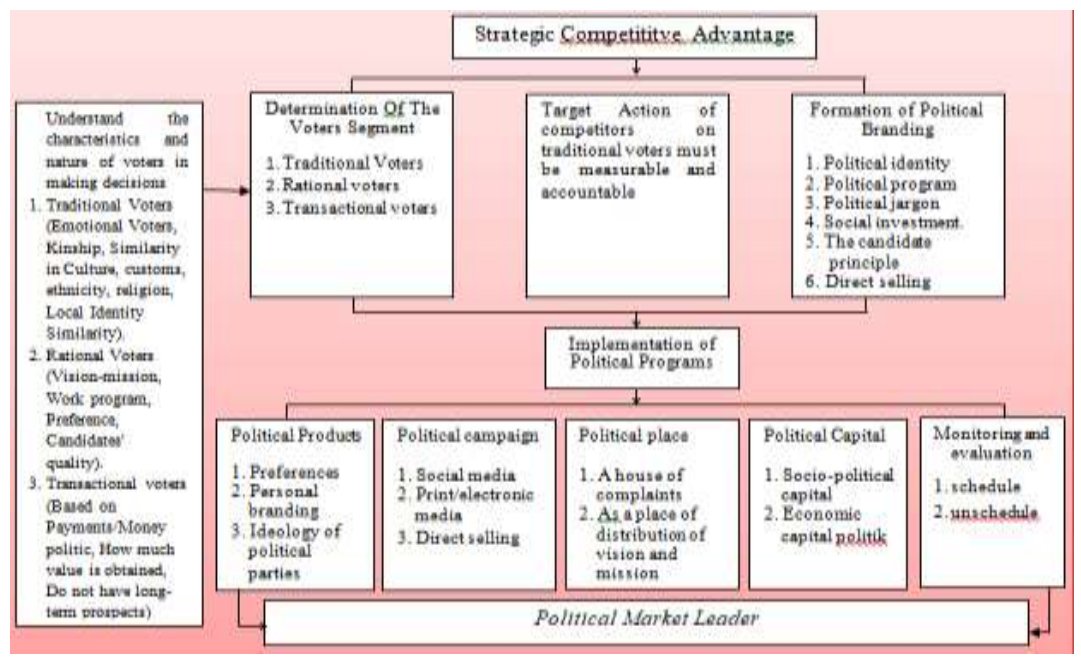

Figure 2. The strategy model of the campaign team of Samahuddin-La Ntau Source : Research findings, 2019

\section{CONCLUSION}

The strategy of the campaign team of Samahuddin-La Ntau is proved successful and was winning the Regent election for Central Buton Regency in 2017. Despite Samahuddin-La Ntau is categorized as a newcomer to political competition they have succeeded in becoming the Regent under the role of SAMATAU's campaign team. In addition, the process of planning, implementation, and evaluation of Samahuddin-La Ntau programs that researcher found is also have been supported from several theories and the results of previous studies including (Kotler, 2001, Newman, 1994, Lees-Marsment 2011, Neffinegger 1989).

\section{IMPLICATION}

The findings of this study are besides being an additional knowledge in management science studies, especially in the concentration of strategies, but on the other side also open the horizons of thinking for politicians, where political marketing strategies are systematic approaches to help competitors in winning the political competition. 


\section{SUGGESTION}

This study only uses a single case on one campaign team, and also only one object of research, that is Central Buton Regency. For the future researcher, it is necessary to develop the research subject and the object of research so that the results of the research are more in-depth and more representative of the entire territory of Indonesia.

\section{REFERENCES}

Berry, William D. et al. 2000. Legislative Professionalism and Incumbent Reelection: The Development of Institutional Boundaries. Florida State University

Creswell, W. John.2016. Penelitian Kualitatif dan Desain Riset, Memilih diantara lima pendekatan. Yogyakarta: PustakaPelajar.

Firmanzah. 2008. Pemasaran politik, antara pemahaman dan realitas.Jakarta: Yayasan Obor Indonesia.

Harris, P., \& Lock, A. 2010.Mind the gap: The rise of political marketing and a perspective on its future agenda. European Journal of Marketing. Vol. 44(3-4), Pp. 297-307. https://doi.org/10.1108/0309056101102043

Keith, R. 1960. The Marketing Revolution. Journal of Marketing. 24 (January

Kotler.2001. Manajemen Pemasaran Edisi Milenium, Edisi Ke 10

Kotler, Philips. Sounders, John. Armstrong Gary. Wong, Veronica. 1999. Principel Of Marketing. USA: Prentice Hall Inc. A Simon \& Schuster Company.

Lees-Marshment, J. 2011. The Political Marketing Game.https://doi.org/10.1057/9780230299511

Lock, A., \& Harris, P. 1996. Political marketing - vive la différence. European Journal of Marketing. Vol. 30(10), Pp. 14-24. https://doi.org/10.1108/03090569610149764

Mehta, Parag2009, The Office of the Public Liaison Presidential Transition Team. interviewed post-2008 presidential campaign and transition over the phone, 29 January.

Naig, U. 2016. For AIADMK, high jinks over high burnout. Hindu. Retrieved 12 September 2017, from.India

Neffinegger 1989. Strategies for succsess from the political marketers.The European Journal of Marketing.

Newman, B. I.1994b. The Forces Behind the Merging of Marketing and Politics.Werbeforschung\& Praxis. Vol. 39 ( 2), pp. 41-46

Moleong, Lexy.J. 2016. Metodologi Penelitian Kualitatif. edisi revisi. Bandung: PT. Remaja Rosdakarya

Osuagwu, L. 2008. Political marketing: Conceptualisation, dimensions and research agenda. Marketing Intelligence and Planning. Vol. 26(7), Pp. 793-810. https://doi.org/10.1108/02634500810916726 
O'Cass, Aron. 2001. Political Marketing: AN Investigation of the Political Marketing concept and political market orientation in Australian Politics. European Journal of Marketing.Vol.35 (9/10), Pp. 1003-25.

Peng, Norman \& Hackley, Chris. 2009. Are voters, consumers? A qualitative exploration of the voter-consumer analogy in political marketing. Qualitative Market Research: An International Journal. Vol. 12 No. 2. School of Management, Royal Holloway University of London, Egham, UK

Pich, C.,Armannsdottir, G., \& Spry, L. 2018. An Exploratory Case Study Focusing on the Creation, Orientation, and Development of a New Political Brand: The Case of the Jury Team. Politics and Policy. Vol. 46(1), Pp. 141-181

Phillips, J. M., Reynolds, T. J., \& Reynolds, K.2010. Decision-based voter segmentation: An application for campaign message development. European Journal of Marketing. Vol. 44(3-4), Pp. 310-330.

Potincu, R. C. 2009. Features of the socio-political marketing. Bulletin of the Transilvania University of Brasov. vol. 2, no. 51

Rohr SChneider I. Robert.2002. The Democracy Deficit and Mass Support for an EU-wide Government. Indiana University. JSTOR

Sugiarto, Bowo et al. 2014. Head of regency election winning strategy. Masyarakat, kebudayaan dan politik. Vol. 27 (3), Pp. 149-157. FISIP universitas jendral sudirman. Purwakerto

Vaishnav, Milan \& Guy, Johnathan. 2018. Does Higher Turnout Hurt Incumbents? An Analysis of State Elections in India. SAG

Yin, Robert.K. 2011. case study research: Design And Methods. 4 th Edition. SAGE 